
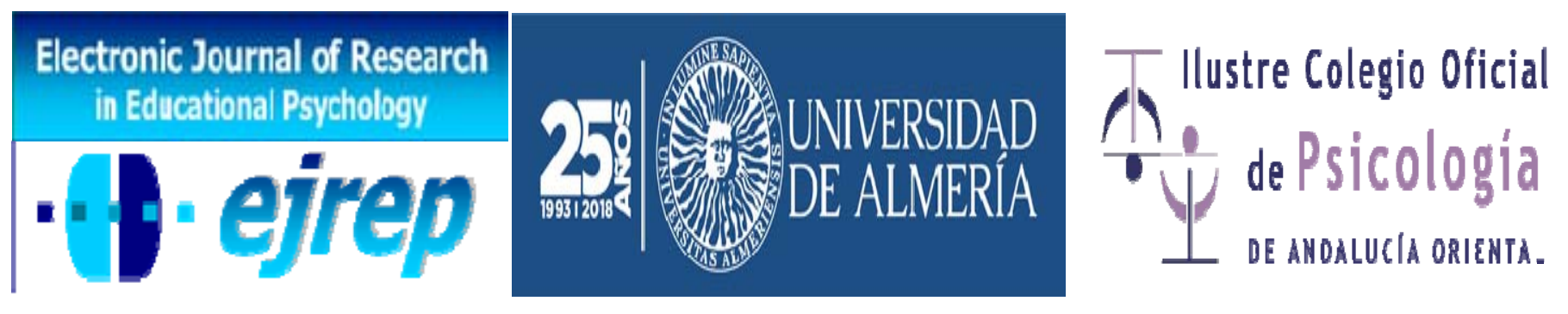

\title{
Procrastination and Learned-Helplessness among University Students: The Mediation Ef- fect of Internal Locus of Control
}

\begin{abstract}
Kususanto Prihadi ${ }^{1}$, Christine Y.H. Tan ${ }^{2}$, Reimy T.S. Tan $^{2}$, Poh Ling Yong ${ }^{2}$, Jonathan H.E. Yong ${ }^{2}$, Sharvini Tinagaran $^{2}$, James L.H. Yeow ${ }^{1}$
\end{abstract}

${ }^{1}$ Lecturers, Department of Psychology, HELP University, Subang 2

${ }^{2}$ Researchers, Department of Psychology, DISTED College, George Town

Malaysia

Correspondence: Dr. Prihadi Kususanto, Department of Psychology. HELP University, Subang 2 Campus Persiaran Cakerawala, 40150 Shah Alam. Selangor, Malaysia. E-mail: prihadi.k@help.edu.my

(C) Universidad de Almería and Ilustre Colegio Oficial de la Psicología de Andalucía Orirental (Spain) 


\begin{abstract}
Introduction. Previous studies indicated that more than $70 \%$ university students committed academic procrastination, and one of the most prominent factors is learned helplessness, the perception that one is incapable of finishing tasks well. It was also hypothesized that when students believe that they are in control of their own events, their learned helplessness will not significantly predict their academic procrastination. This current study aims to test the hypothesis whether internal locus of control mediates the relationship between learned helplessness and academic procrastination among university students.
\end{abstract}

Method. A total of 240 university students were randomly recruited to participate in this current study. Duttweiller's Internal Control Scale was utilized to measure the internal locus of control, Pure Procrastination Scale (adapted for academic setting) was employed to measure the academic procrastination level and Learned Helplessness Scale was used to measure the level of learned helplessness among the participants. Multiple regression with PROCESS macros was employed to analyze the data.

Results. Results indicated that learned helplessness signifcantly predicted internal locus of control, and that internal locus of control was a significant predictor of academic procrastination. These results support the mediational hypothesis. Learned helplessness was no longer a significant predictor of academic procrastination after controlling for the internal locus of control, consistent with full mediation. Approximately $21 \%$ of the variance in academic procrastination can be explained by the predictors. Indirect coefficient was significant. Learned helplessness was associated with approximately .15 points higher academic procrastination scores as mediated by internal locus of control

Discussion and Conclusion. Internal locus of control fully mediates the influence of learned helplessness on academic procrastination. In other words, when students believe that they are in control of their events, the less likely they will procrastinate doing their tasks due to helplessness they have learned. Findings of this study suggested that procrastination in academic setting occurred due to the perception of helplessness that have been learned over time; nevertheless, the influence will not be that deteriorating towards the students when the they believe that they are responsible and in control of their events.

Keywords: academic procrastination, learned helplessness, locus of control, mediation. 


\section{Resumen}

Introducción. Estudios previos indicaron que más del 70\% de los estudiantes universitarios cometieron demoras académicas, y uno de los factores más destacados es la indepensión aprendida, la percepción de que uno es incapaz de terminar bien las tareas. También se planteó la hipótesis de que cuando los estudiantes creen que tienen el control de sus propios eventos, su indefensión aprendida no predecirá de manera significativa su dilación académica. Este estudio tuvo como objetivo probar la hipótesis de si el "lugar interno de control" media la relación entre la indefensión aprendida y la dilación académica entre los estudiantes universitarios.

Método. Un total de 240 estudiantes universitarios fueron reclutados al azar para participar en este estudio actual. Se utiñizó la Escala de Control Interno de Duttweiller para medir el locus de control interno; la Escala de Procrastinación Pura (adaptada para el entorno académico) se usó para medir el nivel de dilación académico; y la Escala de Indefensión Aprendida se usó para medir el nivel de desamparo aprendido entre los participantes. Se utilizó regresión múltiple con macros de PROCESO para analizar los datos.

Resultados Los resultados indicaron que la indefensión aprendida predijo significativamente el locus interno de control, y que el locus interno de control fue un predictor significativo de la dilación académica. Estos resultados apoyan la hipótesis mediacional. La indefensión aprendida ya no era un predictor significativo de la dilación académica después de controlar el locus de control interno, consistente con la mediación completa. Aproximadamente el $21 \%$ de la variación en la dilación académica puede explicarse por los predictores. El coeficiente indirecto fue significativo. La indefensión aprendida se asoció con aproximadamente .15 puntos más altos de puntuación de procrastinación académica mediada por el locus de control interno

Discusión y conclusión. El locus de control interno media completamente la influencia de la indefensión aprendida en la dilación académica. En otras palabras, cuando los estudiantes creen que tienen el control de sus eventos, es menos probable que pospongan sus tareas debido a la impotencia que han aprendido. Los hallazgos de este estudio sugirieron que la postergación en el entorno académico se produjo debido a la percepción de indefensión que se ha aprendido a lo largo del tiempo; sin embargo, la influencia no será tan deteriorada hacia los estudiantes cuando crean que son responsables y tienen el control de sus eventos.

Palabras clave: dilación académica, desamparo aprendido, locus de control, mediación. 


\section{Introduction}

Procrastination of academic tasks have been a serious problem among university students at any levels, because academic procrastination is reported to be a significant factor of low academic achievements (Klassen, Krawchuk, \& Rajani, 2008). However, it was reported that $70-95 \%$ of undergraduate students who experienced academic delays had procrastinate on their academic tasks (Steel, 2010). It can be stated that, academic procrastination requires more attention from education stakeholders due to its negative significance on academic achievements. Studies in more than two decades had been investigating the factors of academic procrastination (Fritzsche, Young, \& Hickson, 2003; Johnson \& Bloom, 1995; Klassen, Krawchuk, \& Rajani, 2008; Solomon \& Rothblum, 1984) and they have reported that individual factors, such as self-regulation and motivation predicted academic procrastination. Other variables that were reported to be dominant in those previous Works are belief that one is incapable of finishing task on time due to negative self-evaluation, which led to learned helplessness (learned helplessness), as well as the belief that one is in control of their own events, or internal locus of control (ILC).

Symbolic interaction theory (Blumer, 1962; Stryker, 1968) explains that individuals value themselves based on their perception on others' expectation; in other words, the way an individual perceives the expectation of others contributes to how the individual evaluates oneself (Rock, 2016). Contextually, academic procrastination can be seen as an outcome of the students perception of their lecturers' expectation towards them. A study by Prihadi, Hairul and Hazri (2010) suggested that when students perceived that they are not expected to perform academically well, they will perceive themselves as academically helpless and will postpone doing their tasks until the last minute. Further study from Prihadi, Hairul and Hazri (2012) suggested that despite the students perceive that they are not expected to perform well, they will not perceive themselves to be helpless as long as they believe that they are in control of their own events (possessing ILC). These aforementioned studies led to a hypothesis that ILC alters how learned helplessness predicts academic procrastination.

\section{Factors of Academic Procrastination}

Studies over decades indicated that academic procrastination can be triggerred internally (by the procrastinators themselves) or externally (by the social environment of the procrstinators). Variables such as laziness, stress and motivation (He, 2017), as well as self- 
regulation failure (Klassen, Krawchuk, \& Rajani, 2008; Rakes \& Dunn, 2010), self-esteem (Duru \& Balkis, 2017), self-determined motivation (Rakes \& Dunn, 2010), and self-efficacy (Klassen et al., 2008; Steel, 2010) have been reported to be the internal factors of procrastination. Factors such as negative evaluation from others (Saddler \& Buley, 1999), and peer influence (Chen, Shi, \& Wang, 2016) are the examples of external factors of academic procrastination.

However, based on the symbolic interaction theory (Blumer, 1962; Stryker, 1968), these external factors need to be perceived in certain ways before eventually lead to procrastination behavior (Rock, 2016). In other words, despite the educators and peers keep telling the procrastinators that they are capable of finishing the task on time, their own perception towards what educators and peers' expectation will contribute to their actual behavior (Wäschle, Allgaier, Lachner, Fink, \& Nückles, 2014); procrastination might still occur, as long as the procrastinators believe that they are incapable of doing the tasks and nobody is there to help them. In line with that, a study by Chen et al (2016) reported that when students developed a belief that their peers expect them to procrastinate and did not offer any help to avoid it, they would likely to procrastinate on their tasks. Chan and his colleagues also mentioned that students who resist to develop such a belief will not procrastinate, despite their peers might expect them to do so.

\section{Learned Helplessness as Predictor}

Theory of symbolic interaction(Blumer, 1962; Stryker, 1968) explained that individuals evaluate themselves based on their perception on others' expectation towards them. In the context of the study, learned helplessness is seen as an outcome of the students' perception of the expectation of their social environment; in other words, when the students perceived that their lecturers and peers do not expect them to perform academically well, they will think that they are incapable of performing well, and eventually they 'learned' that they are academically hopeless and helpless.

In line with the the symbolic interaction theory, when negative feedback is frequently given to less efficacious individuals, they develop negative evaluation on their capabilities and fall into irrational cognition (Steel, 2010) that eventually brings them to the perception of being helpless (Johnson, Rosen, \& Levy, 2008). In turn, the feeling of being helpless brought 
them to academic procrastination; because they believe that they are not capable in finishing the tasks successfully without external support.

In the context of university students, it was reported that young adults with negative evaluation towards self and life tend to develop procrastination behavior (Steel, 2010; Steel \& Ferrari, 2013). In the same context, belief of being helpless is related to ones' perception that academic tasks are beyond their control, aversive, and inescapable that led to further negative perception that it is pointless to finish the task on time (Carden, Bryant, \& Moss, 2004). Another way to explain learned helplessness in academic setting is by seeing it as a product of negative expectancy of academic results, which is predicted by past experience of low academic performance, as well as perception of the absence of social support (Klassen, et al., 2008). It can be assumed that individuals with negative self-perception unconsciously delay their academic works in order to justify their being helpless and the tasks being unbearable.

The way learned helplessness predicts academic procrastination was reported in some studies in different dynamics. One of them suggested that procrastination acts as a selfhandicapping strategies (Park \& Sperling, 2012) or incubator for learned helplessness in some way (Duru \& Balkis, 2017); they procrastinate to confirm that they cannot finish their tasks without any help. In this case, procrastinators have learned that they do not have enough competence to finish the task on time, and keep delaying the work in order to be self-assured that they are incompetent, hence it is acceptable to feel helpless. Other studies reported that procrastinators who learned that they are helpless tend to reflect their task-competency to selfworth (Burka \& Yuen, 2008), which means that making errors in task completion will hurt their pride. Therefore, they avoid doing the task because they perceive that their self-worth or pride will be at stake when they make any error (Duru \& Balkis, 2017). In other words, they keep delaying the work due to the fear of making errors; procrastination serves as a defense mechanism to protect their self-worth.

Contribution of learned helplessness on academic procrastination was also reported in a study where problems with resilience, coping strategies, and psychological well-being occured in the life of university students (Sagone \& De Caroli, 2014). The aforementioned factors tend to put individuals into an alienated stage, where emotional and social supports, such as spiritual activities or counseling are highly required. In such cases, the belief of being helpless 
dragged the individuals to the level where they believe that they are incapable of doing the task properly, yet they still try to cope with it; hence the procrastination (Abbasi \& Alghamdi, 2015). At the same tone, another study reported that individuals who conceal their true performance abilities to secure their sense of self-worth are more likely to postpone to start or delays the completion of tasks (Sirois, 2004). In other words, academic procrastination might also serve as a strategy to cope with the learned helplessness, as a better alternative than totally abandoning the academic tasks.

Symbolic interaction theory and the aforementioned studies suggested that learned helplessness predicts academic procrastination in several ways. The first one is that the learned helplessness made the students felt incompetent, and keep delaying their work to justify their being helpless. The second one is that academic procrastination serves as a defense mechanism to protect the self-worth from being hurt by the perceived-incompetence due to learned helplessness, and another one is being as a coping strategy; learned helplessness made individuals feel incompetent in doing the task, but they try to cope with it by procrastinating the task, rather than not doing it at all. Either way, it was suggested that the learned helplessness predicts academic procrastination.

\section{Mediation of locus of control}

Locus of control theory (Rotter, 1954) stated that individuals with internal locus of control (ILC) tend to credit or blame themselves for their events. Consistently, despite individuals with ILC also rely on their perception of others' expectancy in evaluating themselves, they still believe that their events are in their own control (Prihadi, Hairul, \& Hazri, 2012). Individuals with ILC might still develop learned helplessness because it is significantly predicted by the negative experience (in the form of failure) regarding a certain task (Park \& Sperling, 2012); nevertheless, they believe that they are responsible for their own failures in the past.

Association between locus of control and academic procrastination had been reported in some studies with mixed directions. Individuals with ILC tend to relate their successes and achievements to themselves, thus granting them a sense of responsibility for their actions, which in turn lessen their procrastination behavior (Procházka, et al., 2014); nevertheless, no significant difference of academic procrastination between individuals with internal and external locus of control have been reported (Mishra \& Munjal, 2015; Philips, 2012). In the con- 
text of university students, ILC was reported to predict lower academic procrastination and higher academic achievements (Carden, Bryant, \& Moss, 2004). At the same tone, it was also reported that the higher the ILC levels, the more the students perceived themselves as academically efficient (low level of academic procrastination); in turn, it leads them to positive self-evaluation, which helps them to avoid academic procrastination in the future (Sagone \& De Caroli, 2014).

Relationship between ILC and learned helplessness was also reported in psychological fields other than educational, and various directions were reported. For instance, a study of Grekhov, Suleymanova and Adamovich (2016) suggested that ILC negatively predicted learned helplessness among patients with chronic disease; the belief of being helpless were reported to be lower among patients who believed that their attitude of life might affect the severity of their illness. On the other hand, April, Dharani and Peters (2012) reported that the balance between internal and external locus of control predicts lower level of learned helplessness, instead of ILC alone. Another direction of relationship was advocated by Lemoine (2016), who reported that learned helplessness negatively affects ILC; once the helplessness is learned, individuals will develop external locus of control by showing low effort and put blame on anything but themselves.

\section{Theoretical and Conceptual Framework}

Despite the inconsistent directions have been reported regarding the association between ILC and procrastination as the predictor as well as learned helplessness as the criterion variable, mediation role of ILC can still be hypothesized based on symbolic interaction theory and the study of Lemoine (2016) who stated that ILC is predicted by the learned helplessness, and other studies (Carden et al., 2004; Sagone \& De Caroli, 2014), which stated that ILC predicts academic procrastination. Furthermore, other studies (Abbasi \& Alghamdi, 2015; Steel, 2010; Steel \& Ferrari, 2013) suggested that learned helplessness positively contributes to academic procrastination. The direction of the association among the three variables suggested that the connection between learned helplessness and academic procrastination might be mediated by ILC. The mediation model of the three variables are illustrated in Figure 1. 


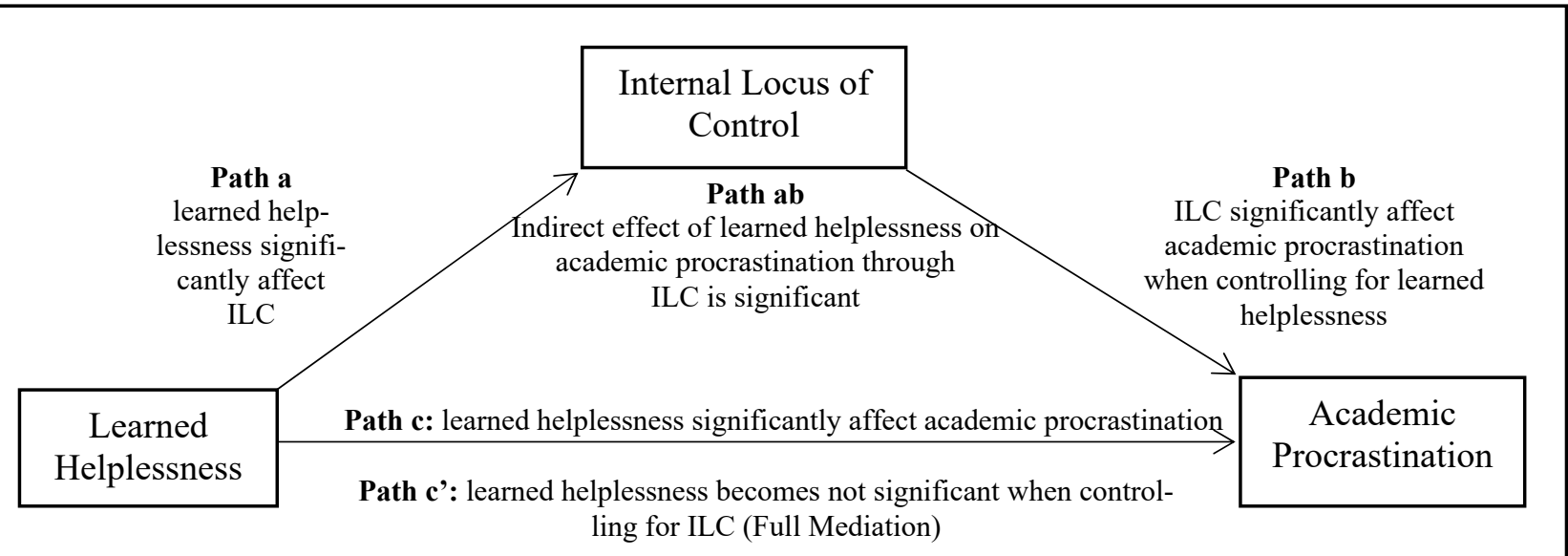

Figure 1. Hypothetical mediation of ILC on the relationship between learned helplessness and academic procrastination

Figure 1 illustrated the hypothetical relationship among the three variables that fits the conditions of mediation by Baron and Kenny (1986), who stated that the predictor variable should contribute to both criterion variable and mediator variable, and that the significance of the predictor on criterion will be altered when controlling for the mediator.

\section{Objetives and hypothesis}

The overarching objective of this current study is to investigate the mediating role of ILC on the relationship between learned helplessness and academic procrastination among university students. Therefore, the following hypotheses are to be tested:

1. learned helplessness positively predicts academic procrastination

2. learned helplessness negatively predicts ILC

3. ILC negatively predicts academic procrastination

4. ILC mediates the influence of learned helplessness on academic procrastination

\section{Method}

\section{Participants}

The participants was composed of 240 university students from several higher education institutions in Malaysia. The mean age of participants was $20.85(\mathrm{SD}=9.2)$, consisted of 116 males and 124 females. All of them are undergraduate students with the composition of 94 juniors, 84 sophmores, 62 seniors. 


\section{Instruments}

ILC was measured by employing Duttweiller's Internal Control Scale (ICI) (Duttweiler, 1984). The ICI consists of 28 items with response alternatives that fall along 5point scale from (A) 'rarely' to (E) 'usually'. academic procrastination was measured by employing Pure Procrastination Scale (PPS) (Steel, 2010). The PPS consists of 9 items with response alternatives that fall along 5 likert scale. learned helplessness was measured by employing Learned Helplessness Scale (LHS) (Quinless \& Nelson, 1988). The scale was consisted of 50 Likert scale items. Demographic data, such as gender, age, nationality, major, and place of study were included in the questionnaire. A pilot study on 60 participants have been conducted, and Cronbach Alpha reliability scores of $.93, .84$ and .72 were obtained for ICI, PPS, and LHS respectively.

\section{Procedure}

Participants participated voluntarily by completing a multi-section, online questionnaire, approved in advance by the Ethic Review Board of DISTED College, and ELM Graduate School of HELP University, Malaysia. The completion of the scales required approximately 30 minutes, consent form was included for the participants to read and approve before responding to the scales. Participants were also given choice to cancel their participation in the midst of responding to the scales in case they would rather not to continue. More than 240 participants responded to the online questionnaire; nevertheless, some of them were not included in the demography of undergratue students, age between 18 to 25 , and registeresd to higher education institution in te state where the study was conducted.

\section{Data Analysis}

The mediation role of ILC was analyzed by following four steps of from Baron and Kenny (1986) on the aforemetioned conceptual framework in Figure 1, which can be defined as follows: 1. Finding the effect of the learned helplessness on the academic procrastination (path c). 2. Finding the effect of the learned helplessness on the ILC (path a). 3. Finding the effect of the learned helplessness and ILC on the academic procrastination (path $\mathrm{c}^{\prime}$ ). 4. Comparing the standardized regression coefficient (beta value) and significance ( $p$ value) of learned helplessness on academic procrastination between path $\mathrm{c}$ and path $\mathrm{c}^{\prime}$ (where ILC is controlled). Partial mediation occurrs when there is a difference between beta values of path $\mathrm{c}$ and c', yet the significance remains; full mediation occurrs when the influence of predictor (learned helplessness) becomes not significant when mediator variable (ILC) is controlled. 


\section{Results}

SPSS software with PROCESS macros was utilized in order to analyze all the path ad the results are compiled in the following Table 1.

Table 1. Results of the mediation analyses of each path

\begin{tabular}{|c|c|c|c|c|}
\hline path a & path $b$ & path c & path $a b$ & path $c^{\prime}$ \\
\hline $\mathrm{F}(1,58)=28.63$ & $F(2,57)=7.67$ & $F(1,58)=10.38$ & $(b=.79)$ & $F(2,57)=7.67$ \\
\hline$p<.001$ & $p=.011$ & $p=.002, \mathrm{R}^{2}=1.52$ & $\mathrm{BCaCI}[.143, .315]$ & $\mathbf{p}=.011$ \\
\hline $\mathrm{R}^{2}=.33$ & $\mathrm{R}^{2}=.21$ & & Does not contain zero & $\mathrm{R}^{2}=.21$ \\
\hline $\begin{array}{l}b=-.76 \\
t(58)=-.5 .35 \\
p<.001\end{array}$ & $\begin{array}{l}\text { Controlled for } \\
\text { learned helplessness } \\
b=-.16 \\
t(57)=-2.09 \\
p=.041\end{array}$ & $\begin{array}{l}\mathrm{b}=.27 \\
\mathrm{t}(58)=3.98 \\
\mathrm{p}=.02\end{array}$ & & $\begin{array}{l}\text { Controlled for inter- } \\
\text { nal locus of control } \\
b=.15 \\
t(57)=1.51 \\
p=.14\end{array}$ \\
\hline
\end{tabular}

Results in Table 1 can be translated into the conceptual framework as illustrated in Figure 2 below:

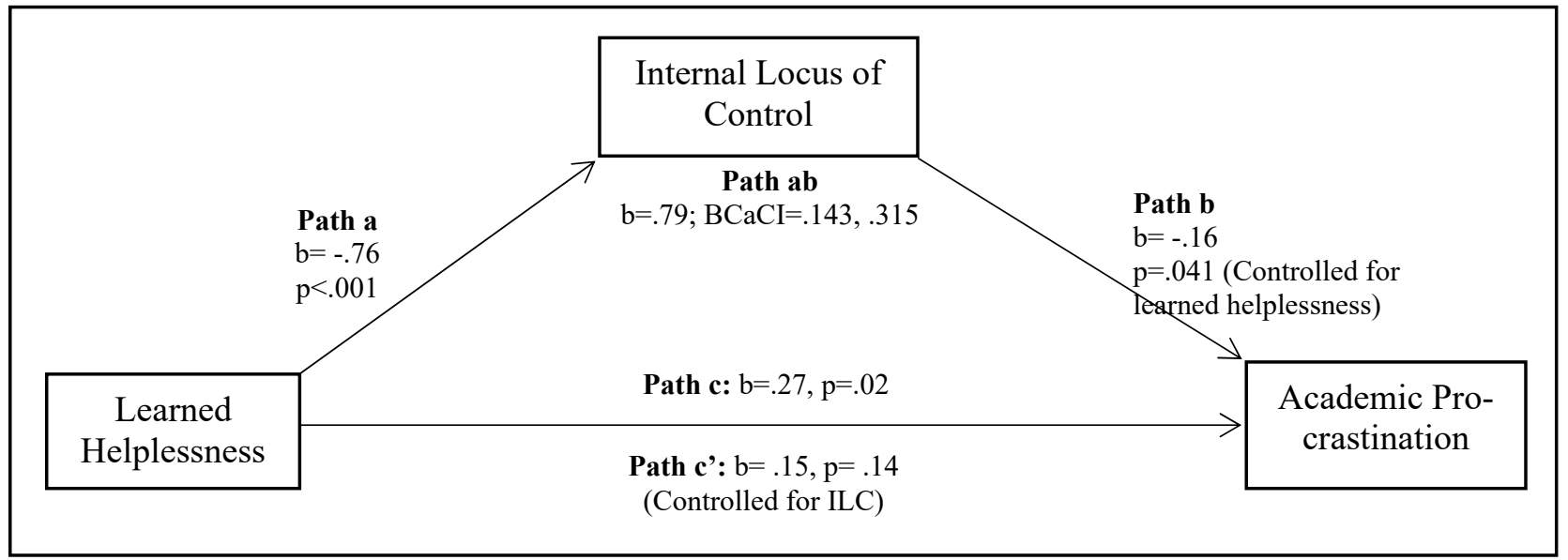

Figure 2. Full Mediation of ILC on the Relationship between learned helplessness and academic procrastination

Table 1 and Figure 2 depict the interrelationship among variables. Path a shows that learned helplessness negatively predicts the ILC, and the prediction is significant, $[\mathrm{F}(1,58)=28.63, \mathrm{~b}=-.76, p<.001]$. It means that one point increment of the learned helplessness of an individual, the ILC will experience about $7.6 \%$ decrease. In path $b$, it was shown 
that ILC negatively contributes to academic procrastination, and the contribution is significant, $[\mathrm{F}(2,57)=7.67, p=.002]$ when controlled for learned helplessness [ $\mathrm{t}(57)=-2.09, p=.041]$ in other words, the more internal the ILC, the less likely one would show academic procrastination behavior. Path c shows that learned helplessness significantly predicts academic procrastination $\left[F(1,58)=10.38, p=.002, \mathrm{R}^{2}=1.52\right]$; which means that higher level of the helplessness learned by individuals predicts higher likelihood of academic procrastination.

Significance of the indirect effect between learned helplessness and academic procrastination through ILC was shown as path ab, as the bias-corrected bootstrapped confidence interval does not contain zero $\mathrm{BCaCI}=.143, .315$. Furthermore, total mediation can be seen in path c', that shows insignificant contribution of learned helplessness on academic procrastination when controlled for ILC $[\mathrm{t}(57)=1.51, \mathrm{p}=.14(\mathrm{~ns})]$. Full mediation indicated that when the students develop the belief that they are in control of their own event, they would not likely be affected by the learned helplessness. The results also indicated that students with procrastination tendency are also students who tend to believe that their success and failure are out of their control.

\section{Discussion}

Findings of this current study are in line with the findings of the previous studies, which reported that students who believe that they were helpless tend to develop academic procrastination behavior (Duru \& Balkis, 2017; Johnson \& Bloom, 1995; Park \& Sperling, 2012). Among this type of procrastinators, academic tasks are perceived to be overwhelmingly uncontrollable and threatening, up to the point where they believe paying adequate effort to finish them on time is pointless (Carden, Bryant, \& Moss, 2004). This finding is also consistent with the study of Steel and Ferrari (2013), who reported that the perception of helplessness led students to academic procrastination. In other words, because they believe that they are not capable to do what it takes to perform well, they would feel that even if they submit their work on time, nothing good will happen. This phenomenon is captured perfectly by the statistical finding that learned helplessness significantly predicts academic procrastination $(b=.27, \mathrm{p}=.02)$. Furthermore, negative prediction on learned helplessness on ILC was also statistically reported significant, $[b=-.76, p<.001]$. This finding is consistent to the argument that when the belief of helplessness increased, individuals would likely to develop another belief that they are not in control of their own events (Lemoine, 2016). On top of that, 
the full mediation of ILC indicated that learned helplessness will not significantly contribute to academic procrastination when the students have developed adequate belief that their success is within their own control.

\section{Practical Implication}

Findings of this study suggested that academic procrastination will not take place when the social environment of the students do not make them learn and believe that they are helpless or lack of ability to perform acacemically well. Additionally, when they are treated in such a way they do not feel helpless, they will also be empowered to develop a belief that their academic succsess is within their control. It is also suggested by the findings of this current study that this sequence will reduce the academic procrastination behavior among university students, because the decrease of learned helplessness, as well as the increase of ILC lead to the decrease of academic procrastination.

Thereby, it is suggested that lecturers should deliver their lessons in such a way where the students will not feel that the subject is unmanageable; instead, the students should feel that the subject might be hard, but they can get it done after some learning process. Students should also learn that they are not helpless, despite they find that some subjects are hard; they should learn that the biggest academic support they can find is from their own self, that are committed to submit the task on time. In line with that, lecturers might also need to explore any methods to improve the students ILC; they have to make sure that the students are aware that they can always try their best and get support from the lecturers when their efforts are not enough.

\section{Suggestions}

Studies with larger number of participants with larger range of demography is suggested to be done in the near future. It is strongly suggested to involve the usage of big data from crowdsourcing in order to maximize the randomization and the scope of demography. Despite cultural diversity might play some roles in determining the levels of learned helplessness or locus of control, it is natural that most culture despise academic procrastination; results of such studies will serve as a benchmark for academicians and education stakeholders to study further on how to eliminate academic procrastination. 
It is worthwhile to include other variables, whether internal, such as personality, upbringing, perceived parenting styles, or external, such as classroom size, classroom engagement and peer pressure. Further studies on reducing academic procrastination based on this current study is highly encouraged, because it is believed that when the academic procrastination is reduced, general academic achievements of the students will increase significantly.

\section{Acknowledgement}

This paper is based on the study supported by internal research grant scheme (IRGS) from ELM Graduate School, HELP University, Malaysia. 


\section{References}

Abbasi, I. S., \& Alghamdi, N. G. (2015). The Prevalence, Predictors, Causes, Treatment, and Implications of Procrastination Behaviors in General, Academic, and Work Setting. International Journal of Psychological Studies, 7(1), 59. DOI: 10.5539/ijps.v7n1p59

April, K. A., Dharani, B., \& Peters, K. (2012). Impact of locus of control expectancy on level of well-being. Review of European Studies, 4(2), 124. DOI: 10.12691/ajnr-4-2-3

Baron, R. M., \& Kenny, D. A. (1986). The moderator-mediator variable distinction in social psychological research: Conceptual, strategic, and statistical considerations. Journal of personality and social psychology, 51(6), 1173. http://dx.doi.org/10.1037/00223514.51.6.1173

Blumer, H. (1962). Society as Symbolic Interaction. In A. M. Rose, Human Behavior and Social Process: An Interactionist Approach. Boston: Houghton-Mifflin.

Burka, J. B., \& Yuen, L. M. (2008). Procrastination: Why you do it, what to do about it. Cambridge: Da Capo Press.

Carden, R., Bryant, C., \& Moss, R. (2004). Locus of control, test anxiety, academic procrastination, and achievement among college students. Psychological reports, 95(2), 581-582. doi:10.2466/pr0.95.2.581-582

Chen, B. B., Shi, Z., \& Wang, Y. (2016). Do peers matter? Resistance to peer influence as a mediator between self-esteem and procrastination among undergraduates. Frontiers in psychology, 7, 1-6. doi: 10.3389/fpsyg.2016.01529

Duru, E., \& Balkis, M. (2017). Procrastination, self-esteem, academic performance, and wellbeing: A moderated mediation model. International Journal of Educational Psychology, 6(2), 97. DOI: 10.17583/ijep.2017.2584

Duttweiler, P. C. (1984). Internal control index: a newly developed measure of locus of control. Educational and Psychological Measurement, 44(2), 209-221. http://dx.doi.org/10.1177/0013164484442004

Fritzsche, B., Young, B. R., \& Hickson, K. (2003). Individual differences in academic procrastination tendency and writing success. Personality and Individual Differences, 35(7), 1549-1557. https://doi.org/10.1016/S0191-8869(02)00369-0

Grekhov, R. A., Suleymanova, G. P., \& Adamovich, E. I. (2016). Locus of Control and Learned Helplessness Phenomenon in Patients with Chronic Internal Diseases. Vestnik Volgogradskogo Gosudarstvennogo Universiteta. Seriâ 11. Estestvennye Nauki, 15(1), 74-8. DOI: https://doi.org/10.15688/jvolsu11.2016.1.8 
He, S. (2017). A Multivariate Investigation into Academic Procrastination of University Students. Open Journal of Social Sciences, 5, 12-24. DOI: 10.4236/jss.2017.510002

Johnson, J. L., \& Bloom, A. M. (1995). An analysis of the contribution of the five factors of personality to variance in academic procrastination. Personality and Individual Differences, 18(1), 127-133. https://doi.org/10.1016/0191-8869(94)00109-6

Johnson, R. E., Rosen, C. C., \& Levy, P. E. (2008). Getting to the core of core selfevaluation: A review and recommendations. Journal of Organizational Behavior, 29, 391-413. doi:http://doi.org/ ft6547

Klassen, R. M., Krawchuk, L. L., \& Rajani, S. (2008). Academic procrastination of undergraduates: Low self-efficacy to self-regulate predicts higher levels of procrastination. Contemporary Educational Psychology, 33(4), 915-931. https://doi.org/10.1016/j.cedpsych.2007.07.001

Lemoine, D. (2016). The process of self-discovery: learned helplessness, self-efficacy, and endogenous overoptimism. http://dx.doi.org/10.2139/ssrn.2768511

Park, S. W., \& Sperling, R. A. (2012). Academic procrastinators and their self-regulation. Psychology, 3(1), 12. DOI:10.4236/psych.2012.31003

Prihadi, K., Hairul, N. I., \& Hazri, J. (2010). Students' Self-Esteem and their Perception of Teacher Behavior: A Study of Between-Class Ability Grouping. Electronic Journal of Research in Educational Psychology, 8(2), 707-724. ISSN:1696-2095

Prihadi, K., Hairul, N. I., \& Hazri, J. (2012). Mediation Effect of Locus of Control on the Causal Relationship between Students' Perceived Teachers' Expectancy and SelfEsteem. Electronic Journal of Research in Educational Psychology, 10(27), 713-736. ISSN:1696-2095

Quinless, F., \& Nelson, M. (1988). Development of a measure of learned helplessness. Nursing Research, 37(1), 11-15. http://dx.doi.org/10.1097/00006199-19880100000003

Rakes, G. C., \& Dunn, K. E. (2010). The Impact of Online Graduate Students' Motivation and Self-Regulation on Academic Procrastination. Journal of Interactive Online Learning, 9(1), 78-93. DOI: 10.12691/education-5-8-5

Rock, P. (2016). Making of symbolic interactionism. Springer.

Rotter, J. B. (1954). Social learning and clinical psychology. doi:http://dx.doi.org/10.1037/10788-000

Saddler, C. D., \& Buley, J. (1999). Predictors of academic procrastination in college students. Psychological Reports, 84(2), 686-688. http://dx.doi.org/10.2466/PR0.84.2.686-688 
Sagone, E., \& De Caroli, M. E. (2014). Locus of control and academic self-efficacy in university students: The effects of Self-concepts. Procedia-Social and Behavioral Sciences, 114, 222-228. https://doi.org/10.1016/j.sbspro.2013.12.689

Sirois, F. M. (2004). Procrastination and counterfactual thinking: Avoiding what might have been. British Journal of Social Psychology, 43, 269-286. doi:http://doi.org/fbzv8

Solomon, L. J., \& Rothblum, E. D. (1984). Academic procrastination: Frequency and cognitive-behavioral correlates. Journal of counseling psychology, 31(4), 503.

Steel, P. (2010). Arousal, avoidant and decisional procrastinators: Do they exist? Personality and Individual Differences, 48, 926-934. https://doi.org/10.1016/j.paid.2010.02.025

Steel, P., \& Ferrari, J. (2013). Sex, education and procrastination: an epidemiological study of procrastinators' characteristics from a global sample. European Journal of Personality, 27(1), 51-58. https://doi.org/10.1002/per.1851

Stryker, S. (1968). Identity Salience and Role Performance: The Relevance of Symbolic Interaction Theory for Family Research. Journal of Marriage and Family, 30(4), 558564. doi:10.2307/349494

Wäschle, K., Allgaier, A., Lachner, A., Fink, S., \& Nückles, M. (2014). Procrastination and self-efficacy: Tracing vicious and virtuous circles in self-regulated learning. Learning and instruction, 29, 103-114. https://doi.org/10.1016/j.learninstruc.2013.09.005 